\title{
Prediksi Harga Saham Garuda Indonesia di Tengah Pandemi Covid-19 Menggunakan Metode ARIMA
}

\author{
Wilda Yulia Rusyida ${ }^{*}$, Versiandika Yudha Pratama ${ }^{2}$ \\ 1,2 Institut Agama Islam Negeri Pekalongan \\ *wilda.yulia.rusyida@iainpekalongan.ac.id
}

\begin{abstract}
ABSTRAK
Penelitian ini bertujuan untuk mengetahui keakuratan metode ARIMA dalam melakukan peramalan atau prediksi harga saham harian PT. Garuda Indonesia, Tbk di tengah pandemi Covid-19. Data yang digunakan dalam penelitian ini yaitu data sekunder berupa data historis harga saham harian sejak 22 April 2019 sampai 20 April 2020. Dari hasil penelitian dengan menggunakan model ARIMA $(3,1,2)$ menunjukkan bahwa data 22 April 2019 sampai 20 April 2020 dapat digunakan untuk memprediksi harga tutup saham 21 April 2020 sampai 13 Juli 2020. Model ARIMA terbaik yang diperoleh adalah ARIMA $(3,1,2)$ dimana harga saham PT. Garuda Indonesia, Tbk hari ini dipengaruhi oleh satu hari perdagangan yang lalu. Prediksi harga saham harian PT. Garuda Indonesia, Tbk di Bursa Efek Indonesia dari 21 April 2020 sampai 13 Juli 2020 cenderung mengalami penurunan. Hal ini di duga karena investor cenderung menahan modalnya efek adanya kebijakan larangan mudik yang diterapkan pemerintah yang berimbas pada berhentinya operasional sektor penerbangan.
\end{abstract}

Kata kunci: metode ARIMA, harga saham, Garuda Indonesia, Covid-19.

\section{ABSTRACT}

This study aims to determine the accuracy of the ARIMA method in forecasting or predicting the daily stock price of PT. Garuda Indonesia, Tbk during the Covid-19 pandemic. The data used in this study are secondary data in the form of historical daily stock price data of PT. Garuda Indonesia, Tbk from April 22nd, 2019 to April 20th, 2020. The result of this study by using ARIMA $(3,1,2)$ method show that the data of April 22nd, 2019 to April 20th, 2020 can be used to predict the closing price of April 21st, 2020 until July 13th 2020. The best ARIMA model obtained is ARIMA $(3,1,2)$ where the stock price of PT. Garuda Indonesia, Tbk today is influenced by one day before. Daily stock price prediction PT. Garuda Indonesia, Tbk on the Indonesia Stock Exchange from April 21 st, 2020 until July 13th 2020 tended to decrease. This is because investors tend to withhold capital from the effects of a ban on returning home policy implemented by the government which has an impact on stopping operational in the aviation sector.

Keywords: ARIMA method, stock price, Garuda Indonesia, Covid-19. 


\section{PENDAHULUAN}

Pasar modal memfasilitasi berbagai sarana dan prasarana kegiatan jual beli dan kegiatan terkait lainnya, dimana didalamnya mencakup sarana pendanaan bagi perusahaan maupun institusi lain (misalnya pemerintah) dan sarana bagi kegiatan berinvestasi yang dilakukan oleh para investor (Darmaji dan Fakhruddin, 2006). Transaksi jual beli harga saham merupakan salah satu bentuk investasi favorit yang dilakukan oleh banyak investor, karena mendapatkan keuntungan yang menjanjikan. Dalam hal ini investor pasti memilih investasi yang mendapatkan keuntungan baginya dengan tingkat kegagalan atau resiko yang kecil (Pandji, dkk. 2019). Hal ini akan bergantung pada setiap harga pada masing-masing harga saham yang kerap berubah dari waktu ke waktu, atau biasa dikenal sebagai data runtun waktu (time series).

Salah satu risiko yang dihadapi dalam membeli saham adalah resiko turunnya harga (capital loss) dan risiko terjadinya likuidasi terhadap perusahaan yang mengeluarkan saham tersebut (Sawidji, 2012). Untuk meminimalkan resiko dalam membeli dan menjual saham, investor harus melakukan analisis mengingat data harga saham yang merupakan data time series yang memiliki aktifitas yang tinggi. Tidak ada saham yang terus menerus mengalami kenaikan sebagaimana juga tidak ada saham yang turun terus menurus, kenaikan dan penurunan yang bergantian seiring dengan bertambahnya waktu menimbulkan beberapa pola. Pergerakan harga saham selama jangka waktu tertentu umumnya membentuk suatu pola tertentu. Oleh karena itu, permalan dirasa sangat perlu untuk mengoptimalkan keuntungan sebagaimana tujuan utama investor di pasar modal (Darsyah dan Nur, 2016).

Salah satu emiten atau perusahaan yang bergerak di pasar modal adalah PT. Garuda Indonesia, Tbk atau biasa dikenal dengan kode emiten GIAA. PT Garuda Indonesia, Tbk merupakan adalah perusahaan penyedia jasa dan layanan penerbangan atau transportasi udara yang ada di Indonesia. PT Garuda Indonesia, Tbk merupakan salah satu BUMN yang sahamnya saat ini dimiliki oleh Pemerintah Indonesia sebesar 60,53\% dan sisanya oleh publik. Di tahun 2020 ini, PT Garuda Indonesia, Tbk mendapatkan sorotan tajam dari para investor terkait harga sahamnya yang cenderung tidak stabil. Hal ini dikarenakan adanya pandemi Covid-19 yang mempengaruhi segala sektor perekonomian di dunia, tak terkecuali sektor perhubungan / transportasi.

Covid-19 (Corona Virus Disease 2019) adalah penyakit akibat serangan virus SARSCov-2 (Severe Acute Respiratory Syndrome Coronavirus 2) atau yang lebih dikenal dengan istilah Virus Corona. Kasus virus corona muncul dan menyerang manusia pertama kali di provinsi Wuhan, China. Awal kemunculannya diduga merupakan penyakit pneumonia, dengan gejala serupa sakit flu pada umumnya. Gejala tersebut di antaranya batuk, demam, letih, sesak napas, dan tidak nafsu makan. Namun berbeda dengan influenza, virus corona dapat berkembang dengan cepat hingga mengakibatkan infeksi lebih parah dan gagal organ. Kondisi darurat ini terutama terjadi pada pasien dengan masalah kesehatan sebelumnya (Mona, 2020).

Virus ini menular ke manusia dan dapat menyebabkan gangguan ringan pada sistem pernapasan, infeksi paru-paru yang berat, hingga kematian. Walaupun lebih banyak menyerang lansia, sebenarnya virus ini dapat menyerang siapa saja, mulai dari balita hingga orang dewasa, termasuk ibu hamil dan menyusui. Karena penularan virus corona yang sangat cepat, Organisasi Kesehatan Dunia (WHO) menetapkan virus corona sebagai pandemi pada 11 Maret 2020. Status pandemi atau epidemi global menandakan bahwa penyebaran COVID-19 berlangsung 
sangat cepat hingga hampir tak ada negara di dunia yang dapat memastikan diri terhindar dari virus corona (Widiyani, 2020). Karena alasan inilah pemerintah di beberapa negara memutuskan untuk menerapkan lockdown atau isolasi total atau karantina.

Karantina menurut UU Republik Indonesia Nomor 6 tahun 2018 tentang Kekarantinaan Kesehatan adalah pembatasan kegiatan dan/atau pemisahan seseorang yang terpapar penyakit menular sebagaimana ditetapkan dalam peraturan perundang-undangan meskipun belum menunjukkan gejala apapun untuk mencegah kemungkinan penyebaran ke orang di sekitarnya (UU No 6 tahun 2018). Beberapa negara yang telah menerapkan lockdown untuk mencegah penyebaran virus corona adalah China, Spanyol, Italia, dan Malaysia. Pemerintah negara tersebut memutuskan lockdown, dengan menutup semua akses fasilitas publik dan transportasi. Warga dihimbau untuk tetap di dalam rumah dan mengisolasi diri, dengan harapan virus tidak menyebar lebih luas dan upaya penyembuhan dapat berjalan maksimal (Perdana, 2020; Kottasova, 2020).

Indonesia sendiri memberlakukan kebijakan Pembatasan Sosial Berskala Besar (PSBB) untuk menekan penyebaran virus ini dengan physical distancing. Penerapan PSBB ini berdampak pada berhentinya kegiatan transportasi massa seperti bus, kereta api, hingga pesawat terbang. Kementerian Perhubungan menyiapkan upaya penyelamatan maskapai penerbangan yaitu dengan membatasi tingkat keterisian kursi pesawat terbang komersial maksimal 50\%. Tidak sedikit penumpang yang membatalkan rencana perjalanan lewat jalur udara seiring adanya pergantian jam operasional. Hal ini menyebabkan penurunan penjualan tiket yang berakibat langsung pada kondisi keuangan perusahaan penerbangan, salah satunya adalah PT. Garuda Indonesia, Tbk. Saham harian PT. Garuda Indonesia, Tbk. cenderung menurun selama periode PSBB yaitu selama bulan Maret-April tahun 2020.

Dengan adanya PSBB yang diterapkan oleh pemerintah, membuat investor berpikir ulang apakah akan menanamkan modalnya di PT. Garuda Indonesia, Tbk ataukah tidak. Oleh karenanya diperlukan suatu analisis mendalam untuk memprediksi harga saham ini ke depannya, salah satunya menggunakan metode ARIMA. Model ARIMA banyak digunakan secara luas dalam melakukan peramalan deret berkala dan banyak penelitian menyebutkan bahwa model ARIMA sangat baik dalam melakukan peramalan beberapa periode ke depan (Kamruzzaman, 2003). Secara umum, model ini dirumuskan sebagai ARIMA (p, d, q), p merupakan orde Autoregressive (AR), d merupakan difference, dan q merupakan orde moving average (MA). Model AR adalah model yang menggambarkan bahwa variabel dependen dipengaruhi oleh variabel dependen pada periode sebelumnya (time lag dari variabel dependen sebagai variabel independen), sedangkan pada model MA, yang merupakan variabel independen adalah nilai residu (error) pada periode sebelumnya. Model AR dan model MA dikombinasikan sehingga menghasilkan model ARIMA (Makridakis, 1999).

Beberapa penelitian terdahulu menggunakan metode ARIMA dalam memprediksi harga saham suatu emiten atau perusahaan. Lilipaly, dkk (2014) menggunakan metode ARIMA untuk melakukan prediksi harga saham PT. BRI, Tbk. Hasilnya model ARIMA untuk harga saham maksimum adalah ARIMA $(2,1,3)$ dan harga saham minimum adalah model $(2,1,3)$ yang dapat digunakan untuk memprediksi data bulan November 2014 dengan validasi prediksi yang diambil pada bulan Oktober 2014. Penelitian lain dilakukan oleh Sadeq (2008) mengenai analisis prediksi IHSG dengan metode ARIMA. Hasil peramalan model ini menunjukkan bahwa model ini cukup akurat dalam melakukan peramalan dengan prosentase kesalahan 
absolut rata-rata sebesar $4,14 \%$. Berdasarkan hal tersebut, peneliti ingin memprediksi bagaimana perkiraan harga saham PT. Garuda Indonesia, Tbk untuk kurang lebih 2 bulan ke depan khususnya saat pandemi Covid-19.

\section{METODE}

Jenis data yang digunakan dalam penelitian ini adalah data sekunder berupa harga saham harian PT. Garuda Indonesia, Tbk pada periode waktu 22 April 2019 sampai 20 April 2020 (255 hari). Sumber data dalam penelitian ini diperoleh melalui penelusuran historical harga saham harian PT. Garuda Indonesia, Tbk pada website resmi yahoo finance maupun Bursa Efek Indonesia.

Penelitian ini menggunakan analisis teknikal. Analisis teknikal pertama kali dilakukan oleh Charles H. Dow pada tahun 1884, dimana Dow menemukan ukuran perhitungan pasar saham miliknya berdasarkan data time series. Disebutkan bahwa teori Dow ini bertujuan untuk mengindentifikasi harga pasar dalam jangka panjang dengan berdasarkan pada data-data historis harga pasar dimasa lalu (Tandelilin, 2001). Menurut Rode, Friedman, Parikh dan Kane (1995) teori dasar analisis teknikal adalah suatu teknik perdagangan yang menggunakan data periode waktu tertentu yang dapat digunakan untuk pengambilan keputusan investasi dengan baik. Jadi obyek dari analisis teknikal adalah memprediksi dari suatu data time series dengan metode peramalan dan perhitungan yang akurat. Keunggulan analisis teknikal ini adalah bahwa mampu memperoleh informasi lebih cepat, sehingga dengan kemampuan para analis dan daya insting yang tajam akan bisa secara langsung menterjemahkannya dalam tindakan menjual dan membeli saham guna memperoleh keuntungan saham (Taswan dan Soliha, 2002).

Salah satu jenis indikator yang digunakan untuk analisis teknikal yang berasal dari data harga saham yang berurutan adalah indikator moving average mengggunakan metode Autoregressive Integrated Moving average (ARIMA). ARIMA merupakan suatu metode yang menghasilkan ramalan-ramalan berdasarkan sintesis dari pola data secara historis (Arsyad, 1995). Model ARIMA merupakan model time series yang digunakan berdasarkan asumsi

bahwa data time series tersebut stasioner artinya rata-rata dan varian $\left(\sigma^{2}\right)$ suatu data time series konstan (Mulyono, 2000).

$$
\phi_{p}(B) \nabla^{d} Z_{t}=\mu+\varepsilon_{t}-\theta_{q}(B) \varepsilon_{t}
$$

dengan

$Z_{t} \quad$ : Nilai pengamatan saat $\mathrm{t}$

$\phi_{p} \quad$ : Parameter autoregresif (autoregresive)

$\theta_{q} \quad$ : Parameter rataan bergerak (moving average)

$B \quad$ : Operator geser mundur

$d \quad$ : Parameter pembedaan (differencing)

$\mu \quad:$ Parameter konstan

$\varepsilon_{t} \quad$ : Nilai sisaan (error)

$p \quad$ : Derajat autoregresive (AR)

$q \quad$ : Derajat moving average (MA) 
Analisis Data dilakukan menggunakan metode ARIMA dengan bantuan software statistika yaitu SPSS versi 26. Langkah - langkah penerapan model ARIMA secara berturut turut adalah sebagai berikut.

1. Pengambilan Data

2. Plot Data

3. Pemeriksaan Kestasioneran Data

4. Penentuan Parameter $\mathrm{p}, \mathrm{d}$ dan $\mathrm{q}$ dalam ARIMA

5. Penentuan persamaan model ARIMA

6. Prediksi

\section{HASIL DAN PEMBAHASAN}

\subsection{Pengambilan Data}

Data harga saham harian PT. Garuda Indonesia, Tbk yang digunakan untuk memprediksi harga saham saat pandemi covid-19 ini diambil dari IDX: GIAA. Data tersebut berupa data runtun waktu (time series). Data yang digunakan untuk memprediksi adalah data harga saham harian PT. Garuda Indonesia, Tbk. dari tanggal 22 April 2019 sampai dengan 20 April 2020 (255 hari).

\subsection{Plot Data}

Terlihat bahwa plot data harga saham harian PT. Garuda Indonesia, Tbk sejak 22 April 2019 sampai dengan 20 April 2020 menunjukkan grafik yang naik turun.

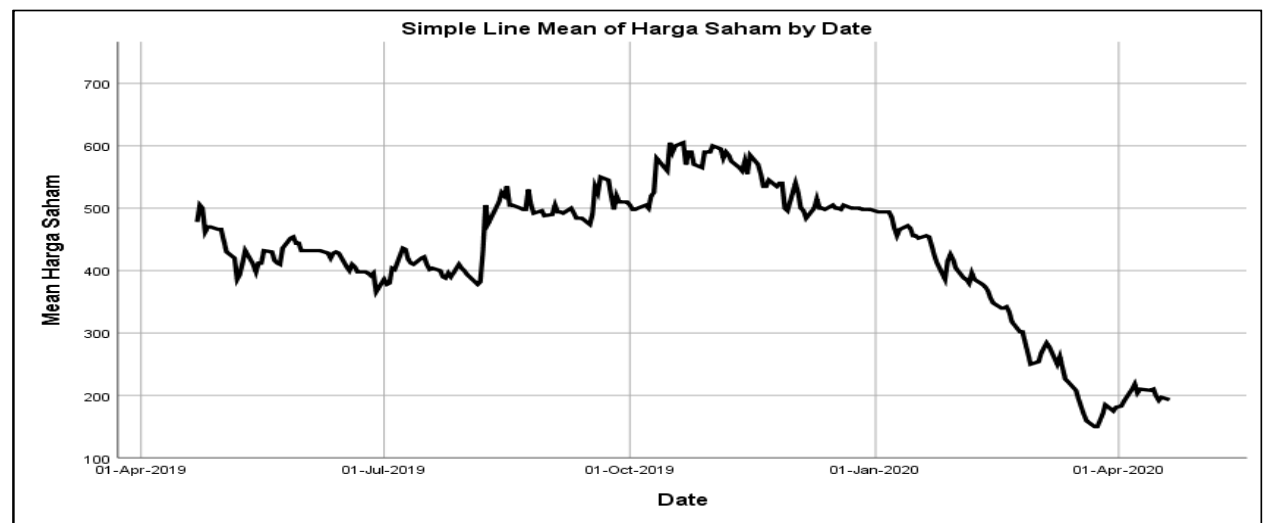

Gambar 1. Plot Data Harga Saham Harian PT. Garuda Indonesia, Tbk 22 April 2019 - 20 April 2020

\subsection{Pemeriksaan Kestasioneran Data}

Kestasioneran data diperlukan untuk memperkecil kekeliruan model. Dari Gambar 1 terlihat bahwa plot data harga saham harian PT. Garuda Indonesia, Tbk. cenderung fluktuatif, artinya data tidak stasioner. Terlihat juga dari plot ACF (Auto Correlation Function) dan PACF (Partial Auto Correlation Function) seperti gambar berikut. 


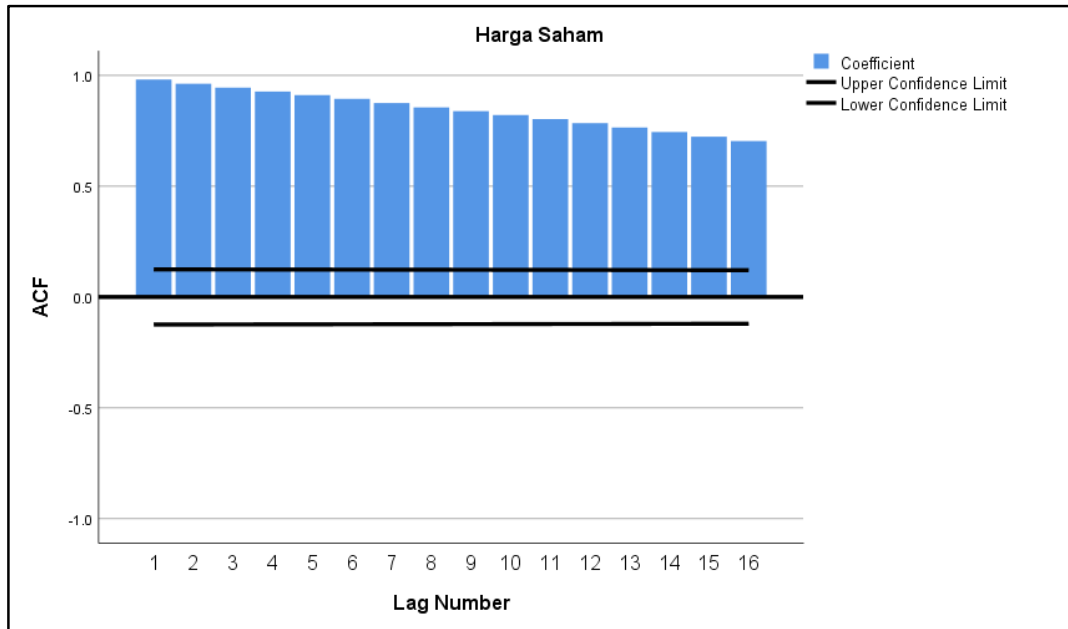

Gambar 2. Plot ACF Data Harga Saham Harian PT. Garuda Indonesia, Tbk 22 April 2019 - 20 April 2020

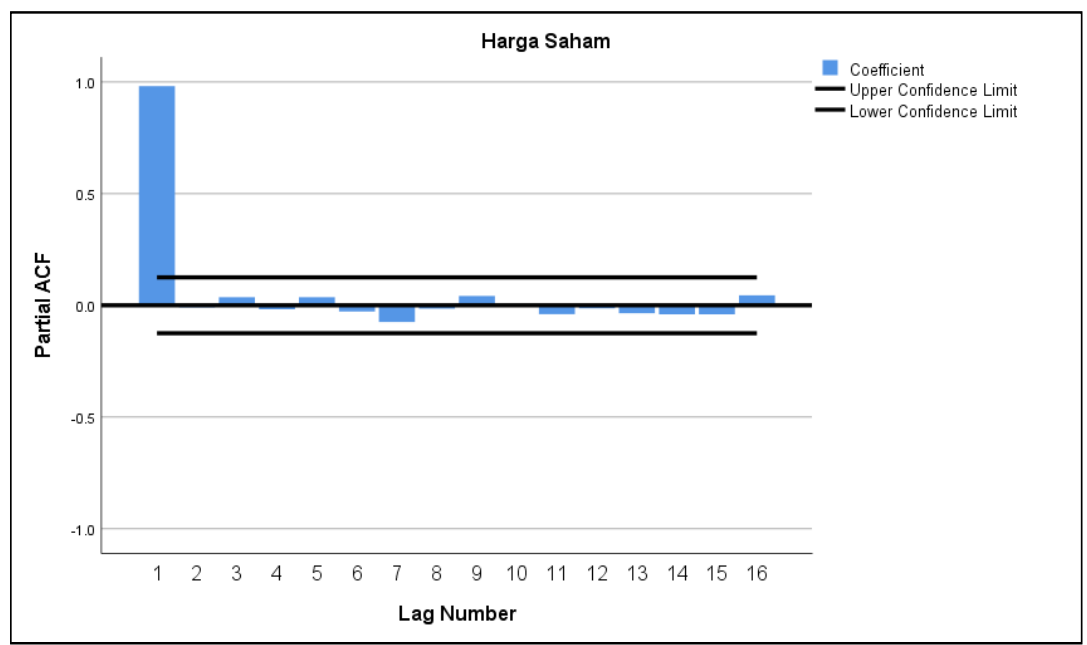

Gambar 3. Plot PACF Data Harga Saham Harian PT. Garuda Indonesia, Tbk 22 April 2019 - 20 April 2020

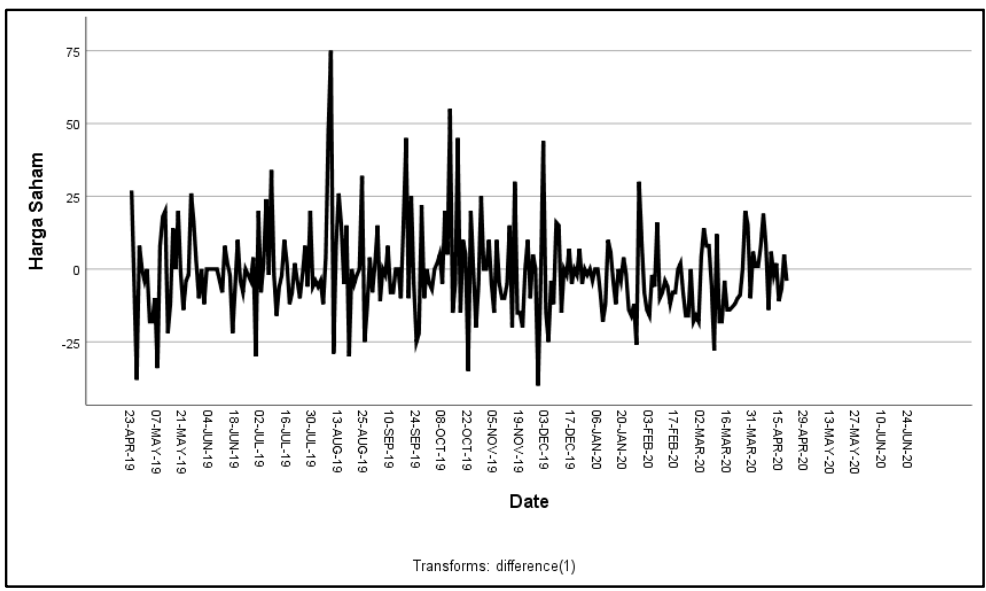

Gambar 4. Sequence plot Data Saham Harian PT. Garuda Indonesia, Tbk 22 April 2019 - 20 April 2020 dengan Selisih Orde 1 
Plot ACF yang cenderung menurun menunjukkan bahwa data tidak stasioner dalam rata-rata, sedangkan plot PACF yang hamper alternating menunjukkan bahwa data tidak stasioner dalam varians. Oleh karena itu, perlu dilakukan proses pembedaan (differencing) agar menjadi data yang bersifat stasioner. Pada Gambar 4 terlihat bahwa setelah dilakukan proses pembedaan dengan tingkat 1, data saham harian PT. Garuda Indonesia, Tbk. bergerak disekitar rata-rata. Dari data tersebut dapat diamati bahwa data sudah bersifat stasioner. Proses pembedaan (differencing) yang telah dilakukan mengidentifikasi bahwa nilai $\mathrm{d}$ yang dapat dipakai adalah $\mathrm{d}=1$.

\subsection{Penentuan Parameter $p, d$ dan q dalam ARIMA}

Selanjutnya akan dipilih parameter/orde model ARIMA yang sesuai dengan menggunakan nilai RMSE (Root Mean Squared Error) dengan rumus sebagai berikut.

$$
R M S E=\sqrt{\frac{\sum\left(y_{i}-\hat{y}_{i}\right)}{n}}
$$

Tabel 1. Penentuan Nilai AR(p), I(d), dan MA(q) dengan nilai RMSE

\begin{tabular}{cccc}
\hline \multicolumn{4}{c}{ Difference $(\mathrm{d}=1)$} \\
Orde & Nilai RMSE & Orde & Nilai RMSE \\
\hline$(1,1,0)$ & 38,92 & $(2,1,2)$ & 38,78 \\
$(1,1,1)$ & 38,69 & $(2,1,3)$ & 38,04 \\
$(1,1,2)$ & 38,61 & $(3,1,0)$ & 38,74 \\
$(1,1,3)$ & 38,36 & $(3,1,1)$ & 38,50 \\
$(2,1,0)$ & 38,95 & $(3,1,2)$ & 38,03 \\
$(2,1,1)$ & 38,66 & $(3,1,3)$ & 38,51 \\
\hline
\end{tabular}

Terdapat 12 model yang didiferensing 1 kali untuk memprediksi harga saham PT. Garuda Indonesia, Tbk sejak 20 April 2019 sampai dengan 20 April 2020. Berdasarkan teori, semakin kecil nilai RMSE yang dihasilkan suatu model maka model semakin baik (Dewi dan Muslikh, 2013). Sehingga diperoleh model dengan RMSE paling kecil yaitu dengan orde $p=3, d=1$, dan $\mathrm{q}=2$ atau ARIMA $(3,1,2)$ dengan hasil nilai RMSE terkecil yaitu 38,03 dan selanjutnya akan digunakan untuk memprediksi data saham harian PT. Garuda Indonesia, Tbk. tanggal 21 April 2020 sampai dengan 13 Juli 2020.

\subsection{Penentuan Persamaan Model ARIMA}

Berdasarkan hasil penentuan orde diperoleh ARIMA $(3,1,2)$ dan output tabel Parameter, diperoleh koefisien sebagai berikut.

\begin{tabular}{|c|c|c|c|c|c|c|c|c|}
\hline \multicolumn{9}{|c|}{ ARIMA Model Parameters } \\
\hline & & & & & Estimate & SE & $t$ & Sig. \\
\hline \multirow[t]{7}{*}{ Harga Saham-Model_1 } & \multirow[t]{7}{*}{ Harga Saham } & \multirow[t]{7}{*}{ No Transformation } & \multicolumn{2}{|l|}{ Constant } & -7.506 & 2.887 & -2.600 & .010 \\
\hline & & & \multirow[t]{3}{*}{ AR, Seasonal } & $\operatorname{Lag} 1$ & .542 & .088 & 6.152 & .000 \\
\hline & & & & $\operatorname{Lag} 2$ & -.848 & .088 & -9.581 & .000 \\
\hline & & & & $\operatorname{Lag} 3$ & .142 & .072 & 1.963 & .051 \\
\hline & & & \multicolumn{2}{|c|}{ Seasonal Difference } & 1 & & & \\
\hline & & & \multirow[t]{2}{*}{ MA, Seasonal } & $\operatorname{Lag} 1$ & .543 & .448 & 1.212 & .227 \\
\hline & & & & $\operatorname{Lag} 2$ & -.996 & 1.638 & -.608 & .544 \\
\hline
\end{tabular}

Gambar 5. Output Tabel Parameter 
Koefisien parameter AR 1: 0,542, AR 2: -0,848, AR 3: 0,142, MA 1: 0,543, MA 2: 0,996, dan konstanta $-7,506$, selanjutnya dibuat persamaan ARIMA menjadi

$$
Z_{t}=-7,506+1,542 Z_{t-1}-1,39 Z_{t-2}+0,99 Z_{t-3}-0,142 Z_{t-4}-0,543 Z_{t-1}+0,996 Z_{t-2} \text {. }
$$

\subsection{Prediksi}

Model ARIMA $(3,1,2)$ digunakan untuk memprediksi harga saham harian PT. Garuda Indonesia, Tbk. tanggal 21 April 2020 sampai dengan 13 Juli 2020 (masa pandemi Covid-19). Adapun grafik prediksi (forecasting) harga sahamnya adalah seperti berikut.

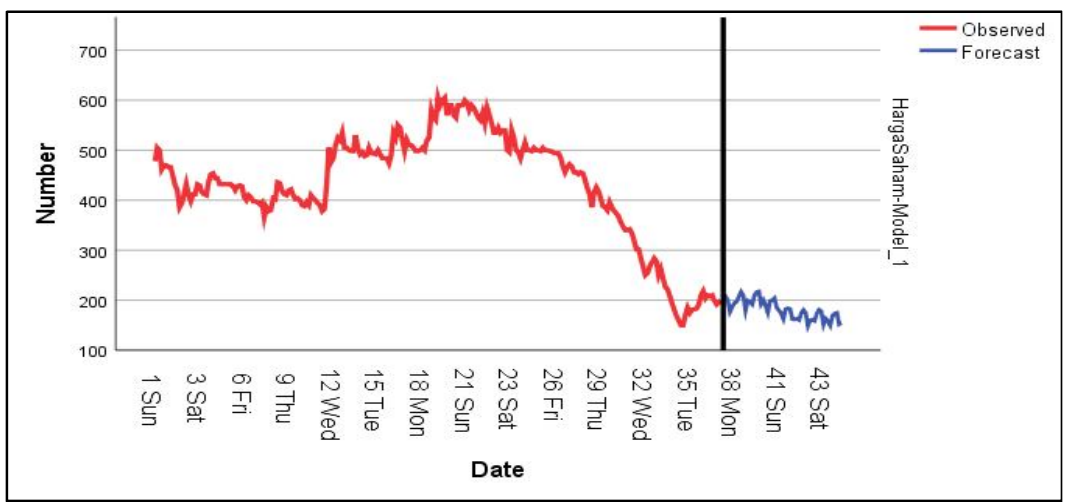

Gambar 6. Grafik Prediksi Harga Saham Harian Bank Indonesia Tanggal 21 April 2020 - 13 Juli 2020

Garis berwarna merah menunjukkan plot data harga saham harian PT. Garuda Indonesia, Tbk. Dari tanggal 22 April 2019 sampai dengan 20 April 2020. Sedangkan garis berwarna biru merupakan prediksi (forecast) harga saham PT. Garuda Indonesia, Tbk pada tanggal 21 April 2020 sampai 13 Juli 2020 yang cenderung turun.

\section{SIMPULAN}

Model untuk memprediksi harga saham PT. Garuda Indonesia, Tbk. pada tanggal 21 April 2020 sampai 13 Juli 2020 yaitu ARIMA $(3,1,2)$ dengan persamaan

$$
Z_{t}=-7,506+1,542 Z_{t-1}-1,39 Z_{t-2}+0,99 Z_{t-3}-0,142 Z_{t-4}-0,543 Z_{t-1}+0,996 Z_{t-2} .
$$

Adapun prediksi nominal harga saham harian PT.Garuda Indonesia, Tbk per tanggal 21 April 2020 sampai dengan 13 Juli 2020 adalah sebagai berikut.

Tabel 2. Prediksi Harga Saham Harian PT. Garuda Indonesia, Tbk Tanggal 21 April 2020 - 13 Juli 2020

\begin{tabular}{cccccccccc}
\hline Tanggal & $\begin{array}{c}\text { Harga } \\
\text { Saham }\end{array}$ & Tanggal & $\begin{array}{c}\text { Harga } \\
\text { Saham }\end{array}$ & Tanggal & $\begin{array}{c}\text { Harga } \\
\text { Saham }\end{array}$ & Tanggal & $\begin{array}{c}\text { Harga } \\
\text { Saham }\end{array}$ & Tanggal & $\begin{array}{c}\text { Harga } \\
\text { Saham }\end{array}$ \\
\hline $21 / 04 / 2020$ & 204 & $08 / 05 / 2020$ & 200 & $28 / 05 / 2020$ & 197 & $15 / 06 / 2020$ & 163 & $30 / 06 / 2020$ & 175 \\
$22 / 04 / 2020$ & 208 & $11 / 05 / 2020$ & 198 & $29 / 05 / 2020$ & 201 & $16 / 06 / 2020$ & 159 & $01 / 07 / 2020$ & 149 \\
$23 / 04 / 2020$ & 201 & $12 / 05 / 2020$ & 192 & $02 / 06 / 2020$ & 182 & $17 / 06 / 2020$ & 173 & $02 / 07 / 2020$ & 161 \\
$24 / 04 / 2020$ & 178 & $13 / 05 / 2020$ & 209 & $03 / 06 / 2020$ & 178 & $18 / 06 / 2020$ & 178 & $03 / 07 / 2020$ & 157 \\
$27 / 04 / 2020$ & 187 & $14 / 05 / 2020$ & 215 & $04 / 06 / 2020$ & 173 & $19 / 06 / 2020$ & 173 & $06 / 07 / 2020$ & 149 \\
$28 / 04 / 2020$ & 195 & $15 / 05 / 2020$ & 215 & $05 / 06 / 2020$ & 161 & $22 / 06 / 2020$ & 148 & $07 / 07 / 2020$ & 167 \\
$29 / 04 / 2020$ & 198 & $18 / 05 / 2020$ & 190 & $08 / 06 / 2020$ & 180 & $23 / 06 / 2020$ & 159 & $08 / 07 / 2020$ & 171 \\
$30 / 04 / 2020$ & 207 & $19 / 05 / 2020$ & 198 & $09 / 06 / 2020$ & 181 & $24 / 06 / 2020$ & 161 & $09 / 07 / 2020$ & 172 \\
$04 / 05 / 2020$ & 217 & $20 / 05 / 2020$ & 188 & $10 / 06 / 2020$ & 180 & $25 / 06 / 2020$ & 158 & $10 / 07 / 2020$ & 149 \\
$05 / 05 / 2020$ & 209 & $26 / 05 / 2020$ & 175 & $11 / 06 / 2020$ & 161 & $26 / 06 / 2020$ & 172 & $13 / 07 / 2020$ & 153 \\
$06 / 05 / 2020$ & 180 & $27 / 05 / 2020$ & 196 & $12 / 06 / 2020$ & 161 & $29 / 06 / 2020$ & 179 & & \\
\hline
\end{tabular}




\section{DAFTAR PUSTAKA}

Arsyad, Lincolin. (1995). Peramalan Bisnis. Jakarta: Ghalia Indonesia.

Darmaji, T., \& Handy, M. Fakhruddin. (2006). Pasar Modal di Indonesia: Pendekatan Tanya Jawab. Jakarta: Salemba Empat.

Darsyah, M. Y., \& Nur, M. S. (2016). Model Terbaik Arima Dan Winter Pada Peramalan Data Saham Bank. Jurnal Statistika Universitas Muhammadiyah Semarang, 4(1).

Dewi, C., \& Muslikh, M. (2013). Perbandingan Akurasi Backpropagation Neural Network dan ANFIS untuk Memprediksi Cuaca. Journal of Scientific Modelling \& Computation, 1(1), 7-13.

Kamruzzaman, J., \& Sarker, R. (2003). Comparing ANN based models with ARIMA for prediction of forex rates. Asor Bulletin, 22(2), 2-11.

Kottasova, I. (2020). Coronavirus Lockdowns: 24 Hours of Confusion Around the World. Retrieved from CNN Health.

Lilipaly, G. S., Hatidja, D., \& Kekenusa, J. S. (2014). Prediksi Harga Saham PT. BRI, Tbk. Menggunakan Metode ARIMA (Autoregressive Integrated Moving Average). Jurnal Ilmiah Sains, 14(2), 60-67.

Makridakis, Wheelwright, dan McGee. (1999). Metode dan Aplikasi Peramalan edisi ke-2. Jakarta: Erlangga.

Mona, N. (2020). Konsep Isolasi Dalam Jaringan Sosial Untuk Meminimalisasi Efek Contagious (Kasus Penyebaran Virus Corona Di Indonesia). Jurnal Sosial Humaniora Terapan, 2(2).

Mulyono, Sri. (2000). Peramalan Harga Saham dan Nilai Tukar : Teknik Box-Jenkins. Jurnal Ekonomi dan Keuangan Indonesia, Vol. XLVIII No.2

Pandji, B. Y., Indwiarti, I., \& Rohmawati, A. A. (2019). Perbandingan Prediksi Harga Saham dengan model ARIMA dan Artificial Neural Network. Indonesia Journal on Computing (Indo-JC), 4(2), 189-198.

Perdana, P. R. (2020). Syarat Ketat Lockdown, RI Sanggup Nggak?. Retrieved from detik.Finance

Rode, David and Parikh, Satu and Friedman, Yolanda and Kane, Jeremiah. (1995). An Evolutionary Approach to Technical Trading and Capital Market Efficiency. The Wharton School University of Pennsylvania.

Sadeq, A. (2008). Analisis prediksi indeks harga saham gabungan dengan metode arima (studi pada IHSG di bursa efek Jakarta). Doctoral dissertation, program Pascasarjana Universitas Diponegoro.

Sawidji, S. (2012). Cara Cepat Memulai Investasi Saham Bagi Pemula Edisi Revisi. Jakarta : Gramedia

Tandelilin, Eduardus. (2001). Analisis Investasi dan Manajemen Portofolio, edisi pertama. Yogyakarta: BPFE

Taswan dan Euis Soliha. (2002). Perspektif Analisis Pelaku Investasi dan Spekulasi di Pasar Modal. Fokus Ekonomi, Vol.1 No.2 Agustus hal.157-166

Widiyani, R. (2020). Latar Belakang Virus Corona, Perkembangan hingga Isu Terkini. Retrieved from detik News 